\title{
Hanna Kupś
}

Uniwersytet Mikołaja Kopernika, Toruń

\section{Instytucje muzyczne w starożytnych Chinach}

Celem niniejszej pracy jest przybliżenie odbiorcy historii i struktury instytucji muzycznych w starożytnych Chinach oraz odpowiedź na pytanie, czy ogół urzędów, które w starożytnych Chinach zajmowały się zbieraniem i redagowaniem utworów oraz edukacją i występami muzycznymi, można określić mianem „biurokracji”.

Praca podzielona jest na trzy części. W pierwszej, stanowiącej wprowadzenie, zdefiniowano termin „biurokracja” oraz przytoczono jego chińskie odpowiedniki. W części drugiej opisano czynniki mające wpływ na powstanie instytucji, których działalność związana była z muzyką, oraz ich ewolucję (ze względu na ograniczenia wynikające z charakteru niniejszej pracy skupiono się na wybranych poglądach filozofii konfucjańskiej i najważniejszych urzędach muzycznych). Ostatnia część zawiera podsumowanie ich cech wspólnych i porównanie z przedstawioną we wstępie definicją „biurokracji”.

W artykule stosowana jest periodyzacja zaproponowana przez słynnego badacza historii muzyki chińskiej, Huang Xiangpenga (黃翔 鵬), zgodnie z którą starożytność podzielona jest na trzy główne epoki: okres muzyki i tańca do czasów dynastii Qin (先秦樂舞 xiān Qín yuèwǔ), pieśni i tańców z akompaniamentem muzyki instrumentalnej (歌舞伎樂 gēwǔ jìyuè, wczesny - od dynastii Qin do Jin; i późny - w czasach dynastii Sui i Tang) i okres muzyki teatralnej (劇曲音樂 jùqū yinnyuè, wczesny - od Pięciu Dynastii do dynastii Yuan; i późny - dy- 
nastie Ming i Qing) ${ }^{1}$. Tematyka niniejszej pracy koncentruje się na okresie muzyki i tańca do czasów dynastii Qin oraz pieśni i tańców $\mathrm{z}$ akompaniamentem muzyki instrumentalnej.

W artykule zastosowano tradycyjny zapis znaków chińskich oraz powszechnie przyjętą transliterację języka chińskiego Hanyu Pinyin (漢語拼音). Odstępstwem od tej zasady są znane polskiemu odbiorcy nazwy własne i geograficzne, wyrażone zgodnie z polską tradycją naukową. O ile nie zaznaczono inaczej, wszystkie tłumaczenia pochodzą od autorki.

\section{Definicja „biurokracji”}

Termin „biurokracja” (fr. bureau - biuro, gr. krátos - władza) został użyty po raz pierwszy w 1745 roku przez Vincenta de Gourneya (1712-1759) i odnosić się może do:

- systemu zarządzania, w którym decydującą rolę odgrywa administracyjny aparat urzędniczy;

- grupy ludzi zawodowo trudniącej się administrowaniem i organizacją pracy instytucji państwowych ${ }^{2}$.

W zależności od ustroju, biurokracja może być oparta na decyzjach (edyktach, ukazach) panującego władcy (w systemach politycznych, gdzie władza skupiona jest w rękach monarchy) lub może być częścią władzy wykonawczej, regulowaną prawem i nadzorowaną przez sądy i władzę polityczną (np. w demokracji konstytucyjnej) (Kamiński 2001: 131-132).

Termin „biurokracja” od samego początku budził negatywne skojarzenia. De Gourney określał biurokrację jako „chorobę zwaną biuromanią”, a Honoré de Balzac (1799-1850) mówił o niej jako o „gigantycznej władzy pigmejów" (Giddens 2004: 369-370). W Procesie

\footnotetext{
${ }^{1}$ Przytoczona powyżej periodyzacja pochodzi z wykładu Huang Xiangpenga wygłoszonego na zaproszenie zespołu muzycznego Han-Tang Yuefu (漢唐 樂府) w listopadzie 1993 roku w Taipej i spisanego w formie artykułu przez Cui Xiana (崔 憲) i Yang Yunhui ( 陽 韻慧) (http://www.cqvip.com/read/read.aspx?id=1002190158, dostęp: 201512-12; powyższa data dotyczy wszystkich źródeł internetowych cytowanych w niniejszym artykule).

${ }^{2}$ Stownik Języka Polskiego pod redakcją W. Doroszewskiego: http://sjp.pwn.pl/szukaj/biurokracja.html.
} 
Franza Kafki jawi się ona jako pełen grozy labirynt, wywołujący poczucie bezsilności. Uzasadnione są zatem i takie definicje:

- biurokratyzm - przerost formalistyki w działalności urzędów, powodujący opieszałe lub niekompetentne załatwianie przez nie spraw, przy obojętności wobec interesu jednostki i dobra ogólnego;

- władza oderwana od mas i narzucająca masom decyzje sprzeczne z ich interesami i wolą; biurokratyzacja, proces odrywania się instytucji od potrzeb społeczeństwa, któremu ma służyć (Suchodolski 1962: 824).

Jednym z pierwszych i jednocześnie najbardziej wpływowych badaczy biurokracji był niemiecki socjolog Max Weber (1864-1920), który uważał, że rozwój biurokracji jest podstawą istnienia społeczeństwa racjonalnego. W swoim opus magnum pt. Gospodarka i społeczeństwo Weber wyszczególnił następujące cechy biurokracji:

- działalność uregulowana prawnie, o określonym zakresie i kompetencjach, w której zadania są oficjalnymi obowiązkami,

- struktura hierarchiczna, przypominająca piramidę zależności służbowych, w której wyższy urząd nadzoruje działanie niższego,

- funkcjonowanie oparte na pisemnej i archiwizowanej dokumentacji,

- praca na określonym stanowisku wymaga fachowego wykształcenia i nie podlega emocjom urzędnika, który nie jest właścicielem majątku urzędu, a za swoją pracę otrzymuje stosowne wynagrodzenie,

- zarząd biura, szczególnie wyspecjalizowany, musi przejść trening z dziedziny, którą się zajmuje,

- wymagana jest pełna wydajność pracy urzędnika, niezależnie od jego godzin pracy,

- praca zarządu biura opiera się na oficjalnych przepisach prawnych dot. postępowania biznesowego i administracyjnego, które znane są urzędnikowi (Weber 1978: 956-958).

Model biurokracji Webera miał być efektem historycznego rozwoju państwa. Choć dotyczył współczesnych społeczeństw, to autor wskazywał, że już w przeszłości istniały całkiem dobrze rozwinięte biurokracje, w tym chińska (por. Weber 1978). 


\section{Termin „biurokracja” i nazwy instytucji muzycznych w ję- zyku chińskim}

Chińskim odpowiednikiem terminu „biurokracja” jest 官僚 guānliáo, które oznacza również 'biurokratę' lub 'bycie biurokratycznym' (The Contemporary Chinese Dictionary 2002: 713, DeFrancis 1996-2002). W odniesieniu do systemu zasad i sposobów wykonywania czynności w rządzie lub organizacji, zwłaszcza jeśli wydaje się zbyt skomplikowany, używa się określenia „biurokratyzm” (官僚主義 guānliáo zhǔyì) lub „styl biurokratyczny” (官僚作風 guānliáo zuòfēng), a w stosunku do rządowego systemu charakteryzującego się dużą liczbą urzędników (którzy nie są wybierani) oraz kraju, w którym taki system funkcjonuje - „system biurokratyczny” (官僚體制 guānliáo ťżhi) (Wehmeier 2004: 214).

Jak do tej pory, autorka nie spotkała się ze sformułowaniem „biurokracja muzyczna” (音樂官僚 yinnyuè guānliáo) w chińskojęzycznych opracowaniach dotyczących tradycyjnej muzyki chińskiej. Jednostki zajmujące się muzyką określane są mianem „instytucji muzycznych” (音樂機構 yīnyuè jīgòu), a ich ogół nazywany bywa „systemem muzycznym” (音樂體系 yinnyuè ť̌xì), „systemem wykorzystania muzyki” (用樂體系 yòngyuè tǐxì) lub „systemem urzędników muzycznych" (樂官制度 yuèguān zhìdù). Choć niektóre terminy odnoszące się do biurokracji w języku chińskim można uznać za pejoratywne (np. „biurokratyzm” lub „styl biurokratyczny”), nazewnictwo związane z instytucjami muzycznymi ma charakter neutralny.

\section{Filozoficzne podstawy wytworzenia się urzędów muzycznych}

Okoliczności powstania i znaczenie muzyki bardzo wcześnie stały się przedmiotem dociekań starożytnych Chińczyków. Zgodnie z mitologią Państwa Środka, muzykę sprowadził na ziemię, wykradłszy ją z niebios, syn Wielkiego Yu (大禹) - Qi (啟) (Wang 2002: 6). Legendarnych twórców cywilizacji, w tym Nüwę (女媧), Fuxi (伏羲), Boskiego Rolnika (神農 Shénnóng) i Żółtego Cesarza (黃帝 Huángdì), uważano za twórców pierwszych instrumentów i utworów muzycznych. Za bóstwo muzyki i jednocześnie gromów uznawano natomiast Kui (澈) $)^{3}$ - potwora, który wydawał dźwięki, uderzając ogonem o swój brzuch (Zang 2005: 5-6).

3 Według innych podań Kui to imię urzędnika muzycznego na dworze Shuna (舜, patrz s. 7). 
Być może zainteresowanie muzyką wynikało z próby zrozumienia świata i prawideł nim rządzących. Starożytne Chiny były krajem rolniczym, sprzyjające żywioły gwarantowały przetrwanie, ale równie dobrze gwałtowność natury mogła przynieść katastrofalne skutki. Skoro więc dźwięki kojarzono ze zjawiskami przyrodniczymi, nic dziwnego, że muzyka, która je porządkowała, tak szybko skupiła na sobie uwagę chińskich filozofów.

W konfucjanizmie poszczególnym dźwiękom przypisano określone znaczenia. Podstawę stanowiła skala pentatoniczna, w której każdy z elementów wiązano np. ze stronami świata, porami roku czy żywiołami ${ }^{4}$ :

\begin{tabular}{|c|c|c|c|c|}
\hline 宮 gōng & 商 shāng & 角 jué & 徵 zhǔ & 羽 yǔ \\
\hline środek & zachód & wschód & południe & północ \\
\hline $\begin{array}{c}\text { szósty } \\
\text { miesiąc }\end{array}$ & jesień & wiosna & lato & zima \\
\hline ziemia & metal & drewno & ogień & woda \\
\hline
\end{tabular}

Tabela 1. Znaczenia tonów gamy pentatonicznej (Pimpaneau 2001: 230; Olszewski 2003: 211).

Zdaniem starożytnych Chińczyków, dźwięki, które oddawały konkretne, przekładalne na język idee, mogły manipulować emocjami i uczuciami człowieka. W efekcie wytworzyła się koncepcja muzyki „prawidłowej”, czyli takiej, która zaprowadzała wśród ludzi radość, oraz „rozwiązłej” - mającej negatywny wpływ i przyczyniającej się do powstawania chaosu. „Prawidłowa muzyka”, nierozerwalnie związana z konfucjańskim rytuałem, ucieleśniała równowagę, spokój oraz umiejętność adaptacji do zmiennych warunków. Znajomość Księgi Pieśni ${ }^{5}$, muzyki obrzędowej oraz gra na instrumencie strunowym qin (琴) uznawane więc były przez konfucjanistów za podstawę rozwoju i samokształcenia ${ }^{6}$ (DeWoskin [w] Zemanek 2007: 70-75).

${ }^{4}$ Czystość stroju była sprawdzana $\mathrm{w}$ trakcie uroczystości państwowych (Chomiński 1957: 61). Co więcej, w czasach dynastii Han, 12 dźwięków skali odnoszono m.in. do dwunastu cykli w roku. Wierzono, że piszczałki, które je wydawały, poruszane były przez energię $q i$ (氣), której ruch przynosił ze sobą zmiany pór roku zwrotnikowego (DeWoskin [w] Zemanek 2007: 74-75).

5 詩經 Shijing - antologia pieśni, której redakcje przypisywano Konfucjuszowi; zaliczana do Pięcioksięgu konfucjańskiego

(https://www.britannica.com/topic/Shijing).

${ }^{6} \mathrm{~W}$ języku chińskim „ucho” (耳 ér) jest elementem znaczeniowym np. znaku oznaczającego „mądrość” (聰 cōng), pierwotnie oznaczającego „dobry słuch” lub „mędrca” (聖 shèng) (DeWoskin [w] Zemanek 2007: 72). 
Muzyka w konfucjanizmie była rodzajem kulturowego kodu, łączącego dźwięki ze zjawiskami „pozamuzycznymi”. Kluczem do jej zrozumienia jest spojrzenie na nią jako na narzędzie służące do osiągnięcia szeroko rozumianej harmonii. Jak pisał Xunzi ${ }^{7} \mathrm{w}$ swoim traktacie $O$ muzyce:

muzyka wnika w to, co jest jednością, aby ustanowić harmonię; dobiera rzeczy, by ozdobić dyscyplinę; łączy melodie, aby utworzyły piękną formę i dzięki temu pozwala prawidłowo podążać za jednym Dao i wprowadzić ład wśród dziesięciu tysięcy zmian. [...] Zatem muzyka - to wielki porządek na świecie Pod Niebem, osnowa umiarkowania harmonii, coś, czego emocjonalna natura nie może być pozbawiona (Xun Zi [w] Zemanek 2007: 56 ${ }^{8}$ ).

Muzyka, wiązana z ładem i porządkiem, choć mogła pomóc człowiekowi, miała jednak również potencjał, by mu zaszkodzić. Aby pielęgnować dobro w sercu człowieka, należało więc poddać ją pewnym ograniczeniom i kontroli ${ }^{9}$. W praktyce przełożyło się to m.in. na bardzo konserwatywne podejście do pentatoniki, która z biegiem czasu ulegała tylko niewielkim zmianom (Chomiński 1957: 58-60), oraz być może wykształcenie kontroli państwa nad muzyką i zestawem dopuszczalnych w niej dźwięków.

Chiny nie są jedyną kulturą, w której muzyce przypisywano tak wielkie znaczenie. W starożytnym Egipcie dźwięki kojarzono z dniami tygodnia i planetami. Wpływ muzyki na edukację i rozwój człowieka dostrzeżony został również przez Platona, który w swoim dziele Państwo podkreślał etyczny aspekt muzyki i jako sprzyjające rozwojowi kraju uznawał jedynie utwory tworzone w skali doryckiej i frygijskiej. Rzymski uczony Boecjusz ${ }^{10}$ dzielił natomiast muzykę na

7 荀子 Xunzi (300-230 r. p.n.e.) - jeden z głównych filozofów konfucjańskich starożytnych Chin (http://www.britannica.com/biography/Xunzi).

${ }^{8}$ Przekład z języka chińskiego autorstwa dr Małgorzaty Religi.

9 „W Kolejności urzędów mówi się: «Opracowanie zaleceń i rozkazów, baczne przyglądanie się karom i nagrodom, zakaz wyuzdanych melodii, postępowanie zgodne z właściwym czasem, tak by barbarzyńskie obyczaje i zepsute dźwięki nie wprowadzały zamętu do tego, co wzorcowe - oto zadanie wielkiego kronikarza»." (Xun Zi [w] Zemanek 2007: 58)

${ }^{10}$ Anicius Manlius Severinus Boethius (470/475?-524) - rzymski uczony i mąż stanu, chrześcijański filozof, autor Consolatio Philosophiae (http://www.britannica.com/biography/Anicius-Manlius-SeverinusBoethius). 
musica instrumentalis - wokalną $\mathrm{i}$ instrumentalną, musica humana odzwierciedlającą harmonię duszy i ciała oraz równowagę i symetrię między organami i częściami ciała, a także musica mundana, czyli muzykę sfer, zawiadującą ruchami nieba i Ziemi, żywiołami i porami roku11 (Thomas 1995: 12-33).

\section{Instytucje muzyczne w starożytnych Chinach}

\section{Okres muzyki i tańca do czasów Qin}

Najwcześniejsze wzmianki dotyczące profesjonalnych muzyków można odnaleźć już w chińskiej mitologii. Legendy wymieniają cały szereg podwładnych, którzy na rozkaz swoich władców tworzyli i kodyfikowali muzykę, np. na dworze Żółtego Cesarza był to Ling Lun (伶倫) ${ }^{12}$, cesarza Zhuanxu (顓頊) - Fei Long (飛龍), cesarza Diku (帝棠) - Xian Hei (咸黑), cesarza Shao (堯) - Zhi (質), a cesarza Shuna (舜) - Kui (唼) (Zang 2005: 6).

Społeczeństwo w czasach dynastii Zhou (1046-256 p.n.e.) było silnie zhierarchizowane, a najliczniejsi chłopi byli podporządkowani grupie arystokratycznych rodów. Aby utrzymać i jednocześnie uzasadnić ten podział, bardzo szybko ustanowiono system rytuałów, nierozerwalnie połączony $\mathrm{z}$ muzyką ${ }^{13}$. Jednym $\mathrm{z}$ przejawów różnic w hierarchii był na przykład sposób ustawienia instrumentów muzycznych - król miał prawo ustawić je po czterech stronach komnaty, wasale (諸侯 zhūhóu) po trzech stronach, minister (卿 qing) i urzędnicy wysokiego szczebla (大夫 dàfu) - po dwóch, a literati (士 shì) po jednej ${ }^{14}$ (Yang 1981: 33-34).

\footnotetext{
${ }^{11}$ Aby zrozumieć skomplikowane relacje pomiędzy muzyką i językiem, porównaj z Thomas (1995).

${ }^{12}$ Mit o Ling Lunie jest szczególnie istotny, ponieważ zgodnie z przekazami, na rozkaz Żółtego Cesarza wynalazł on 12 dźwięków skali muzycznej (Wang 2002: 6).

${ }^{13}$ Zgodnie z Zapiskami Historyka 禮樂 lǐyuè - muzyka połączona z rytuałem pojawiała się już w 1058 p.n.e. (Yang 1981: 33).

${ }^{14}$ Podobnie, dla każdej z grup określono liczbę tancerzy, która mogła dla nich występować: król mógł cieszyć się występami ośmiu rzędów artystów po osiem osób w każdym, dworzanie o najwyższej pozycji (諸公 zhūgōng) sześciu rzędów po sześć osób, a wasale (諸侯 zhūhóu) czterech rzędów po cztery osoby (Yang 1981: 33-34).
} 
Szczególnie istotna była tzw. muzyka elegancka (雅樂 yăyuè) ${ }^{15}$, czyli muzyka wykorzystywana w ceremoniach składania ofiar Niebiosom, Ziemi oraz przodkom, wykonywana m.in. w świątyniach, na dworze królewskim, na turniejach łucznictwa i w trakcie ceremonii wojskowych. Podstawę stanowiło sześć utworów muzycznotanecznych sławiących dokonania wcześniejszych władców. Były to: Yunmen (雲門), Xianchi (咸池), Dashao (大韶), Daxia (大廈), Dahu (大 濩) oraz Dawu (大武) (Zang 2005: 17-19).

Choć uzasadniano, że tylko dzięki zrozumieniu i podkreśleniu różnic społecznych możliwe jest osiągnięcie szacunku pomiędzy ludźmi (Zang 2005: 18), była to jednak przede wszystkim świadoma próba ugruntowania władzy politycznej. Aby zachować ciągłość mechanizmu rządzenia, konieczne było stworzenie instytucji, która mogłaby zapewnić wykształcenie kolejnych pokoleń zaznajomionych z rytuałami i dlatego w czasach dynastii Zhou powołano Wielki Urząd Muzyki (大司樂 Dàsīyuè) ${ }^{16}$, którego działalność obejmowała administrację i edukację muzyczną oraz przeprowadzanie występów (Yang 1981: 34-35).

Wielki Urząd Muzyki skupiał łącznie 1463 urzędników, z których 1277 było chłopami pańszczyźnianymi (農奴 nóngnú) i tylko około 100 pochodziło z arystokracji (Yang 1981: 34-35). Na czele instytucji stał najwyższy urzędnik (大司樂 Dàsīyuè), który odpowiedzialny był za nauczanie cnót muzycznych (樂德 yuèdé), sposobu wykonywania muzyki (樂語 yuèyǔ) oraz sześciu utworów stanowiących kanon muzyki ceremonialnej. Najwyższemu urzędnikowi podlegali nauczyciele muzyki (樂師 yuèshī) ${ }^{17}$, których można było podzielić na wielkich (大 師 dàshī - nauczali przede wszystkim teorii muzyki) i małych (小師 xiăoshi - nauczali gry na instrumentach). Do pracowników najniższego szczebla należeli zwykli muzycy (樂工 yuègōng) (Zang 2005: 20-

\footnotetext{
${ }^{15}$ Termin yăyuè można również rozumieć jako „muzykę wzorcową”, jednak ze względu na to, że w publikacjach anglojęzycznych jest on częściej tłumaczony jako „muzyka elegancka”, autorka zdecydowała się użyć właśnie tego sformułowania.

${ }^{16}$ Istnieje pewna nieścisłość w odniesieniu do Wielkiego Urzędu Muzyki. Niektórzy badacze wskazują, że „Dàsīyue” było nie tylko tytułem najwyższego urzędnika tej instytucji, ale również całego urzędu (Si 2009: 17); inni, że Wielki Urząd Muzyki podlegał Urzędowi Wiosny (春官 chūnguān) (Shan 2014: 303).

17 Możliwe, że z uwagi na dobrą pamięć muzyczną nauczycielami muzyki bardzo często były osoby niewidome, nazywane 韾 gǔ. Ze względu na posiadane umiejętności dzielono je na trzy grupy: podstawową (上 shāng), średniozaawansowaną (中 zhōng) i zaawansowaną (下 xià) (Zang 2005: 20).
} 
21). Nauki prowadzone przez urzędników Wielkiego Urzędu Muzyki skierowane były głównie do potomków rodów arystokratycznych (w tym króla i wasali), ale wybierano również uczniów o niższym pochodzeniu. Edukacja rozpoczynała się w wieku trzynastu lat i trwała do dwudziestego roku życia (Yang 1981: 34-35).

W czasach Wiosen i Jesieni oraz Wojujących Królestw (770-221 p.n.e.) funkcjonował zwyczaj 采風 căifēeng, czyli dosłownie „zbierania obyczajów", którego głównym celem było rozpoznanie i manipulowanie nastrojami społecznymi. Urzędnicy wysyłani byli do różnych części kraju, by zbierać ludowe utwory muzyczne lub tworzyć nowe w podobnym stylu. Jeśli ich treść nie odpowiadała zamysłom rządzącego, były one modyfikowane lub interpretowane w odpowiedni sposób i ponownie wpuszczane do obiegu, np. w trakcie różnych ceremonii. Zebrane przez urzędników utwory stanowiły podstawę skompilowanej przez Konfucjusza w 484 p.n.e. Księgi Pieśni (Yang 1981: 47).

Pod koniec okresu Wiosen i Jesieni dwór Zhou, a wraz z nim jego muzyka, znajdowały się w kryzysie. Krytykowane przez konfucjanistów melodie z zamieszkiwanych przez Shangów krajów Zhang i Wei, być może ze względu na swój bardziej rozrywkowy charakter, zaczęły zyskiwać ogromną popularność. Ta nieograniczona zasadami rytuału tzw. „nowa muzyka” (新樂 xīnyuè) odsunęła w cień dominującą dotychczas muzykę elegancką. Władcy rosnących w siłę państw wasalnych zaczęli jednak, na wzór upadającej dynastii Zhou, angażować muzyków dworskich i dzięki temu system urzędników muzycznych, choć w zmodyfikowanej formie, przetrwał upadek dynastii Zhou (Si 2009: 16-17, 25).

\section{Wczesny okres pieśni i tańców z akompaniamentem muzyki instru- mentalnej}

W czasach dynastii Han (206 p.n.e.-220 n.e.) utwierdzono się w przekonaniu, że muzyka może być znakomitą metodą wpływania na społeczeństwo. Zgodnie z poglądami filozofa Dong Zhongshu (董 仲舒 179-104 p.n.e.) muzyka powinna pełnić rolę narzędzia rządzenia państwem i być tworzona przez władców tak, by odzwierciedlać cechy charakterystyczne okresu ich panowania. W razie potrzeby, zanim rządzący skomponowali własne utwory, należało odwoływać się do dorobku czasów wcześniejszych (Yang 1981: 135).

Zgodnie z zapiskami, w 112 r. p.n.e. cesarz Han Wudi (漢武帝 156-87 p.n.e.) powołał Biuro Muzyki (樂府 Yuèfǔ) (Yang 1981: 106). Choć główny okres działalności i rozwoju Biura przypadł na czasy dynastii Han, to dzięki odkryciom archeologicznym, takim jak odna- 
lezienie pochodzących z czasów dynastii Qin dzwonu 鈿鐘 niǔzhōng ${ }^{18}$ oraz glinianych pieczęci ${ }^{19}$, na których wyryto znaki 樂府 Yuèfǔ, wiemy, że powstało ono już wcześniej (Si 2009: 38).

Do głównych zadań Biura Muzyki należało zbieranie utworów muzyki ludowej, tworzenie i uzupełnianie do nich słów oraz melodii, dopasowywanie odpowiednich instrumentów muzycznych i organizowanie występów artystycznych. Biuro Muzyki zajmowało się głównie ceremonialną muzyką dworską, wykorzystywaną m.in. w trakcie uroczystości składania ofiar i uczt, oraz muzyką ludową (Yang 1981: 106-108). Kilkudziesięciu urzędników było odpowiedzialnych za warstwę poetycką utworów, a pozostali byli artystami pochodzącymi $\mathrm{z}$ ludu, przyjętymi w charakterze pracowników niższego szczebla (przeszło osiemset osób). Niestety, dokładna struktura Biura Muzyki pozostaje nieznana, do dziś zachowały się jednak imiona jego najważniejszych urzędników: wszechstronnie uzdolnionego kierownika Li Yanniana (李延年 zm. 82 p.n.e.) oraz poety Sima Xiangru ${ }^{20}$ (Yang 1981: 106-107, Si 2009: 38-39).

Wraz z nastaniem panowania cesarza Han Aidi ${ }^{21}$ Biuro Muzyki utraciło swoją wysoką pozycję i w 6 r. p.n.e zostało rozwiązane. Na dworze pozostawiono tylko urzędników, którzy zajmowali się muzyką dworską (388 osób, Yang 1981: 107). Z biegiem czasu nazwy urzędu zaczęto używać nie tylko na określenie utworów zebranych przez Biuro, ale również późniejszych - z czasów dynastii Wei, Jin i Tang oraz imitujących ich styl (Si 2009: 39) ${ }^{22}$.

Zebrane przez urzędników do czasów Północnych i Południowych Dynastii utwory można podzielić na trzy główne typy: muzykę xianghe (相和歌 xiānghégē), muzykę qingshang (清商樂 qīngshāngyuè) oraz muzykę guchui (鼓吹樂 gǔchuīyuè). Muzyka xianghe obejmowała początkowo

${ }^{18}$ Dzwon odnaleziono w 1976 r. w grobowcu pierwszego cesarza Chin - Qin Shihuanga (秦始皇, Si 2009: 38).

${ }^{19}$ Datowane na okres dynastii Qin gliniane pieczęcie znaleziono na obrzeżach miasta Xi'an w 2000 r. (Si 2009: 38).

20司馬相如 (179-117 p.n.e.) - jeden z najwybitniejszych poetów dynastii Han, słynący $\mathrm{z}$ poezji w formie fu (http://encyklopedia.pwn.pl/haslo/SimaXiangru;3975323.html).

${ }^{21}$ Cesarza Han Aidi (27-1 p.n.e.) określano mianem 性不好音 xìng bù hào yīn, czyli „tego, który nie ceni dźwięków” (Si 2009: 39).

${ }^{22}$ Nazwa Yuèfú została po raz pierwszy użyta w odniesieniu do typu poezji przez Liu Xie (刘劦思) w czasach dynastii Liang (502-587) (Huang [w]: Zhongguo Dabaike Quanshu Zongbianji Weiyuanhui «Yinyue, Wudao» Bianji Weiyuanhui (red.) 1998: 834). 
proste pieśni ludowe, śpiewane z akompaniamentem instrumentów dętych i strunowych, które później rozwinęły się w skomplikowaną formę artystyczną łączącą śpiew, muzykę instrumentalną i taniec. Muzyką qingshang określano utwory pochodzące $\mathrm{z}$ doliny jeziora Taihu oraz środkowego i górnego biegu rzeki Jangcy, a muzyką guchui - pieśni północnych grup etnicznych, śpiewane do melodii granych na instrumentach dętych i perkusyjnych (Xia 2007: 8-9).

\section{Późny okres pieśni i tańców z akompaniamentem muzyki in- strumentalnej}

Czasy dynastii Sui i Tang (581-618 i 618-907) zakończyły przeszło stuletnią epokę rozłamu zapoczątkowaną abdykacją cesarza Gonga $\mathrm{z}$ dynastii $\mathrm{Jin}^{23}$. Stabilizacja polityczna i ekonomiczna oraz kontakty z obcymi kulturami przyczyniły się do gwałtownego rozwoju chińskiej muzyki, co znalazło odzwierciedlenie m.in. w wytworzeniu się nowych gatunków i instytucji muzycznych.

System administracji muzycznej osiągnął niespotykane dotychczas rozmiary i opierał się na dwóch głównych filarach: nadzorze Świątyni Taichang (太常寺 Tàichángsì) ${ }^{24}$ i bezpośredniej kontroli dworu. Świątynia była najwyższym organem zarządzającym muzyką rytualną. Na jej czele stał minister (太常卿 Tàichángqing), który był zwierzchnikiem mistrzów muzyki (太常博士 Tàicháng bóshì), dowódców muzycznych (協律都尉 xiélü dūweì) oraz urzędników podlegających mu urzędów: Biura Wielkiej Muzyki (大樂署 Dàyuèshǔ) ${ }^{25}$, Biura Muzyki Guchui (鼓吹署 Gǔchuishǔ) oraz Biura Muzyki Qingshang (清 商署 Qingshāngshǔ) ${ }^{26}$ (Xu 2009: 42).

Biuro Wielkiej Muzyki zajmowało się głównie muzyką elegancką i bankietową (燕樂 yànyuè) ${ }^{27}$, było również organem edukacyjnym,

${ }^{23}$ Cesarz Gong zrzekł się tronu w 420 r. na rzecz cesarza Wu z dynastii Liu Song. Był to początek ery Północnych i Południowych Dynastii.

${ }^{24}$ Świątynia Taichang funkcjonowała już w czasach dynastii Qin pod nazwą 奉常 Fèngcháng. Miano to zostało zmienione w 151 r. za czasów panowania cesarza Jinga $z$ dynastii Han na 太常 Tàicháng (Xu 2009: 42).

${ }^{25}$ Choć w niektórych opracowaniach (w tym Xu (2009)) w odniesieniu do Biura Wielkiej Muzyki stosowana jest nazwa 太樂署 Tàiyuèshǔ, to w przeważającej ilości publikacji występuje termin 大樂署 Dàyuèshŭ, dlatego autorka zdecydowała się na użycie właśnie tego odpowiednika.

${ }^{26}$ Biuro Muzyki Qingshang wymienione jest przez Xu (2009) tylko z nazwy i nie jest omawiane $w$ innych, znanych autorce, publikacjach dotyczących muzyki okresu. Być może była to instytucja wcześniejsza.

27 ～宴樂 yànyuè 
odpowiedzialnym za przeprowadzanie szkoleń i egzaminów. Pracowali w nim profesjonalni nauczyciele, którzy zgodnie z wynikami corocznych testów klasyfikowani byli do trzech grup: podstawowej 上 shàng, średniozaawansowanej 中 zhōng oraz zaawansowanej 下 xià. Co dziesięć lat przeprowadzano kolejną weryfikację umiejętności, na podstawie której urzędnik mógł zostać awansowany, zdegradowany lub utracić stanowisko (Yang 1981: 233-234). Oprócz nauczycieli Biuro zatrudniało również innych muzyków, w tym 140 tancerzy cywilnych i wojskowych (文武二舞郎 wénwǔ èrwǔláng) oraz muzyków specjalizujących się w muzyce ludowej (散樂 sànyuè) i muzyce ludowej wykorzystywanej w trakcie ceremonii (仗內散樂 zhàngneì sănyuè), których było odpowiednio 382 i 1000 (Zang 2005: 94-95).

Wymagania stawiane kandydatom na urzędników, nazywanym „ludźmi dźwięków” (音聲人 yinshēngrén), były bardzo wysokie. Proces edukacyjny trwał od dziesięciu do piętnastu lat, w trakcie których należało przystąpić do przynajmniej pięciu testów podstawowych i siedmiu średniozaawansowanych. Ich niezaliczenie skutkowało pozbawieniem szansy na posadę urzędnika, nawet jeśli uczeń uczestniczył w zajęciach w całym okresie nauczania. Absolwenci musieli wykazać się znajomością ponad pięćdziesięciu trudnych melodii. Uczniowie o słabszych wynikach mogli być oddelegowywani do innych specjalności, a nieznajomość wystarczającej liczby utworów skutkowała zmniejszeniem wynagrodzenia ${ }^{28}$. Poza tym Biuro Wielkiej Muzyki oferowało roczne, dwuletnie lub trzyletnie kursy doszkalające z różnych typów muzyki (Yang 1981: 233).

Działalność Biura Muzyki Guchui wiązała się przede wszystkim z muzyką, od której typu wzięło ono swoją nazwę. Urzędnicy Biura, których było od kilkuset do tysiąca, zajmowali się także muzyką wojskową oraz organizowali muzykę $\mathrm{w}$ trakcie wyjazdów rodziny cesarskiej (Xu 2009: 42).

Bezpośrednio pod jurysdykcją dworu cesarskiego znajdowały się dwa urzędy: Konserwatorium Muzyki (教坊 Jiàofāng) i Sad Gruszowy (梨園 Líyuán). Konserwatorium muzyczne ${ }^{29}$ było początkowo kontrolowane przez Świątynię Taichang, ale od czasów panowania cesarza Xuanzonga (唐玄宗 685-762), w okresie swojej największej świetno-

\footnotetext{
${ }^{28} \mathrm{~Np}$. osoby znające mniej niż dziesięć melodii otrzymywały $1 / 3$ pensji (Yang 1981: 233).

${ }^{29}$ Konserwatorium muzyczne powstało w czasach dynastii Sui. W początkowym okresie dynastii Tang (692 r.) jego nazwa została zmieniona na 雲韶 府 Yúnsháofŭ. Określenie 教坊 Jiàofāng przywrócił cesarz Zhongzong (Xu 2009: 42).
} 
ści, podlegało bezpośrednio władcy i od 714 r. podzielono je na pięć oddziałów: Wewnętrzne Konserwatorium Muzyki (內教坊 Neì Jiàofāng), Lewe i Prawe Konserwatorium Muzyczne w Zachodniej Stolicy Chang'an (西京左右教坊 Xïjing Zuǒyòu Jiàofāng) oraz Lewe i Prawe Konserwatorium we Wschodniej Stolicy Luoyang (東京左右教坊 Dōngiing Zǒuyòu Jiàofāng) (Xu 2009: 42). Do obowiązków Konserwatorium należało kształcenie muzyków oraz nadzorowanie występów muzyki dworskiej. „Prawe Konserwatoria” specjalizowały się w śpiewie, a „Lewe” w pokazach tanecznych. We wszystkich oddziałach pracowało łącznie około 2000 artystów (Zang 2005: 95).

Choć w Konserwatorium pracowali muzycy obu płci (Yang 1981: 234), wydaje się, że prym wiodły kobiety, ponieważ wyszczególniono aż trzy grupy artystek. Pierwszą z nich były „damy dworu” (內人 neìrén $)^{30}$ - artystki na najwyższym poziomie i wykonujące najtrudniejsze utwory, drugą dysponujące pośledniejszymi umiejętnościami „urzędniczki” (宮人 gōngrén) ${ }^{31}$, a trzecią „muzykantki” (搊彈家 chōutánjiā) ${ }^{32}$ - pochodzące z ludu kobiety, które ze względu na swoją urodę i zdolności zostały przyjęte na dwór i były uczone sztuki gry na instrumentach strunowych szarpanych, takich jak pipa, sanxian i konghou (Yu 2010: 59-60).

Sad Gruszowy został założony w 714 r. przez cesarza Xuanzonga i wziął swoją nazwę od ogrodów w pałacu cesarskim. Specjalizował się w występach muzyki $f a q u^{33}$, ale do jego zadań należało również odgrywanie kompozycji samego cesarza, które często wpisywały się w ten typ utworów. Istniały trzy oddziały Sadu: dworski oraz dwa podległe Świątyni Taichang w Chang'an i w Luoyang (odpowiednio Inny Instytut Sadu Gruszowego w Świątyni Taichang 太常梨園別教院 Tàicháng Líyuán Biéjiàoyuàn i Nowy Instytut Sadu Gruszowego 梨園新院 Líyuán Xĩnyuàn) (Yu 2010: 59-60). Poza tym w Sadzie funkcjonował jeszcze Mały Wydział Dźwięków (小部音聲 Xiǎobù yinnshēng), złożony z około trzydziestu dzieci do lat piętnastu, które grały nowe utwory w Pałacu Długowieczności (長生殿 Chángshēng Diàn) (Yang 1981: 236).

Wydaje się, że mimo relatywnie wysokiej specjalizacji, Sad Gruszowy był instytucją o niemałych rozmiarach. W dworskim Sadzie szkoliło się 300 mężczyzn i kilkaset kobiet. Ze względu na to, że byli

${ }^{30}$ 前頭人 qiántourén

31 官人 guānrén

32 掐彈家 qiātánjiā

33法曲 Făqŭ - typ muzyki taoistycznej, popularny na dworze dynastii Tang, czerpiący z muzyki xianghe i qingshang, często korzystający z instrumentów takich jak: nao, bo, zhong, qing, dongxiao, pipa itd. (Xia 2007: 36). 
nauczani przez samego cesarza, określano ich mianem „uczniów cesarskiego Sadu Gruszowego" (皇帝梨園弟子 Huángdì Líyuán Dìž). Co więcej, w filii w Chang'an, gdzie przede wszystkim grano nowe utwory faqu, pracowało tysiąc muzyków, a w Nowym Instytucie, zajmującym się głównie muzyką ludową, kolejnych tysiąc pięćset osób. Prawdopodobnie poziom artystów w Luoyangu i Chang'an był niższy od dworskiego, wyjątkowo uzdolnieni urzędnicy z Luoyangu mogli jednak zostać przeniesieni do Konserwatorium Muzycznego (Yang 1981: 236). Działalność Sadu Gruszowego została rozwiązana w 779 r. przez cesarza Daizonga (Xu 2009: 43).

Instytucje muzyczne w czasach dynastii Song (960-1279), choć na zdecydowanie mniejszą skalę, czerpały z doświadczenia i tradycji swoich poprzedników. Świątynia Taichang wciąż zajmowała się muzyką i rytuałem, ale od 1105 r. zakres jej działalności został ograniczony wyłącznie do administrowania dworskich rytuałów. Kontrolę nad muzyką elegancką przejęła wtedy nowa instytucja - Biuro Wielkiego Blasku (大晟府 Dàshèngfǔ), która jednocześnie przejęła obowiązki dawnego Biura Muzyki Guchui (Yu 2010: 81).

Przed powołaniem Biura Wielkiego Blasku działały jeszcze dwie instytucje specjalizujące się w muzyce guchui: Zespół Junrongzhi (鈞 容直 Jūnróngzhî) i Zespoły Wschodnie i Zachodnie (東西班樂 Dōngxibānyuè $)^{34}$. Obie grupy składały się z utalentowanych muzycznie żołnierzy dworskiej kawalerii, odpowiedzialnych za występy w trakcie wyjazdów cesarza. Artyści Zespołów Wschodnich i Zachodnich grali na stosunkowo niewielkiej liczbie instrumentów, w tym bili35 oraz niewielkich fletach (小笛 xiăo dî) i shengach ${ }^{36}$, natomiast Zespół Junrongzhi, w okresie swojej największej świetności, skupiał około czterystu muzyków, grających utwory gatunków daqu ${ }^{37}$, gudi ${ }^{38}$, qiuci ${ }^{39}$ i innych (Shan 2014: 304, Yu 2010: 82).

\footnotetext{
${ }^{34}$ Zespoły Wschodnie i Zachodnie zostały utworzone w okresie Taiping Xingguo (976-983), a Zespół Junrongzhi działał od 978 do 1160 r. (Yu 2010: 82).

35䇤策 Bìlì ( 悲策 bēilì) - instrument dęty drewniany, mający formę rurki $\mathrm{z}$ dziewięcioma otworami oraz trzcinowym stroikiem. Pochodził z regionu Kucha, leżącego w północno-zachodnim Xinjiangu i pojawił się w Chinach w 384 r. (Yu 2010: 40).

36笙 shēng - instrument dęty stroikowy, zbudowany z siedemnastu bambusowych rurek umieszczonych $\mathrm{w}$ niewielkim zbiorniku $\mathrm{z}$ ustnikiem (https://www.britannica.com/art/sheng-musical-instrument).

${ }^{37}$ 大曲 Dàqǔ - typ występu artystycznego łączący muzykę instrumentalną, śpiew i taniec.
} 
W 960 r. przywrócono Konserwatorium Muzyczne, które podzielono na cztery wydziały ${ }^{40}$ : wydział muzyki daqu, muzyki faqu, muzyki qiuci i muzyki gudi. (Shan 2014: 303-304). Ówczesne niepokoje polityczne zakłócały działalność Konserwatorium ${ }^{41}$, które w związku z najazdami państwa Jin od 1161 r. funkcjonowało już tylko z nazwy i nie zatrudniało muzyków. Poza Konserwatorium, muzyką bankietową zajmował się także Wydział Yunshao (雲韶部 Yúnsháobù) ${ }^{42}$, który był odpowiedzialny za organizację koncertów daqu i występów teatru lalek (Yu 2010: 81).

\section{Podsumowanie}

Instytucje muzyczne w starożytnych Chinach wpisują się w słownikową definicję biurokracji. Niezaprzeczalnie, można określić je jako system zarządzania i grupę ludzi zajmującą się administrowaniem pracy instytucji państwowych, w tym wypadku wyspecjalizowanych w zadaniach związanych z muzyką chińską.

Urzędy muzyczne miały klarownie określone kompetencje i zadania, np. Wielki Urząd Muzyki w czasach Zhou był organem edukacyjnym, Biuro Muzyki w dynastii Han trudniło się zbieraniem i redakcją utworów muzycznych, a Biuro Muzyki Guchui w czasach dynastii Tang odpowiedzialne było głównie za muzykę wojskową i występy w trakcie wyjazdów rodziny cesarskiej.

W każdej z opisanych instytucji istniała hierarchia i podział pracy, której wykonanie było obowiązkowe. Co więcej, przykład m.in. dynastii Tang pokazuje, że do wykonywania zadań niezbędne było fachowe wykształcenie, którego rygorystycznie przestrzegano i od którego mogło zależeć wynagrodzenie urzędnika. Majątek wszystkich wymienionych instytucji nie należał do ich pracowników i był własnością cesarza.

Z drugiej jednak strony, choć swoją wiedzę na temat urzędów muzycznych czerpiemy z zapisków i kronik dawnych chińskich historyków, nie wiemy, w jakim stopniu działanie struktur mu-

38鼓笛曲 Gǔdíqǔ - prawdopodobnie typ muzyki instrumentalnej, granej na fletach i bębnach.

39 龜茲曲 Qiūcíqǔ - muzyka pochodząca z regionu Kucha.

${ }^{40} \mathrm{~W}$ późniejszym okresie Konserwatorium było podzielone na trzynaście różnych wydziałów, z których każdy specjalizował się w innym typie muzyki, np. wydział muzyki granej na bili, dagu, pipa, itd. (Yu 2010: 81).

${ }^{41}$ Konserwatorium zostało rozwiązane w $1127 \mathrm{r}$. i zostało ponownie otwarte w 1144 r. (Yu 2010: 81).

${ }^{42}$ Początkowo nazywany 蕭韶部 Xiāosháobù (Shan 2014: 304). 
zycznych było uregulowane prawnie i jak bardzo ich funkcjonowanie było oparte na dokumentach urzędowych; nie znamy również dokładnych wymagań i wytycznych wyższego szczebla wobec niższego oraz sposobu ich weryfikowania.

Największą przeszkodą $\mathrm{w}$ porównywaniu systemu i charakteru działalności urzędów muzycznych z modelem biurokracji Webera jest brak wystarczającej ilości informacji. Poza tym, rozmyślania Webera odnoszą się do specyficznych struktur i zależności, obcych historycznym realiom Państwa Środka. Biorąc jednak pod uwagę stopień zgodności struktur muzycznych w starożytnych Chinach z zaprezentowanymi definicjami, autorka proponuje, by ich ogół określać jako tradycyjną biurokrację muzyczną.

\section{Bibliografia}

Chomiński, Józef M., Zofia Lissa. 1957. Historia muzyki powszechnej. Tom 1. Do renesansu włącznie. [brak miejsca]: Polskie Wydawnictwo Muzyczne.

The Contemporary Chinese Dictionary: Chinese-English Edition. Xiandai Hanyu Cidian Han-Ying Shuangyu. 2002. Beijing: Foreign Language Teaching and Research Press. Waiyu Jiaoxue yu Yanjiu Chubanshe.

[現代漢語辭典: 漢英雙語. 2002. 北京:外語教學與研究出版社.]

DeFrancis, John. 1996-2002. ABC Chinese-English Dictionary. [brak miejsca]: University of Hawaii. Wenlin Software for Learning Chinese Version 3.0. Wenlin Institute 1997-2002.

DeWoskin Kenneth. 2007. Dawna chińska muzyka a pochodzenie terminologii estetycznej. Tłum. Maria Markiewicz. Adina Zemanek (red.). Estetyka chińska. Antologia. Kraków: TAiWPN Universitas, 65-92.

Giddens, Anthony. 2004. Socjologia. Tłum. Alina Szulżycka. Warszawa: Wydawnictwo Naukowe PWN.

Huang Xiangpeng. 1998. [Biuro Muzyki] Yuefu Zhongguo Dabaike Quanshu Zongbianji Weiyuanhui "Yinyue, Wudao» Bianji Weiyuanhui. [Wielka Encyklopedia Chińska: Muzyka, Taniec] Zhongguo Dabaike Quanshu: Yinyue, Wudao. Pekin: Zhongguo Dabaike Quanshu Chubanshe, 834.

[黃翔鵬. 1998. 樂府. 中國大百科全書總編輯委員會 $<<$ 音樂,舞蹈 $>>$ 編輯委員會. 中國大百科全書: 音樂,舞蹈. 北京: 中國大百科全 書出版社, 834.] 
Kamiński, Antoni Z. 2001. Biurokracja. Dariusz Kalisiewicz (red.). Wielka Encyklopedia PWN. Tom 4. Biblia brzeska - buhaj. Warszawa: Wydawnictwo Naukowe PWN SA, 131-132.

Olszewski, Wiesław. 2003. Chiny. Zarys Kultury. Poznań: Wydawnictwo Naukowe UAM.

Pimpaneau, Jacques. 2001. Chiny. Kultura i tradycje. Tłum. Irena Kałużyńska. Warszawa: Wydawnictwo Akademickie „Dialog”.

Shan, Honglong. 2014. Zhongguo Chuantong Yinyue [Tradycyjna muzyka chińska]. Wuhan: Wuhan Daxue Chubanshe.

[單紅龍. 2014. 中國傳統音樂. 武漢: 武漢大學出版社.]

Si, Binglin. 2009. Zhongguo Yinyueshi Puxiu Jiaocheng [Kurs historii muzyki chińskiej]. Shanghai: Shanghai Yinyue Xueyuan Chubanshe.

[司冰林. 2009. 中國音樂史普修教程. 上海: 上海音樂學院出版社.]

Suchodolski, Bogdan. 1962. Wielka Encyklopedia Powszechna PWN. Tom 1. A-Ble. Warszawa: Państwowe Wydawnictwo Naukowe PWN.

Thomas, Downing A. 1995. Music and the origins of Language. Theories from the French Enlightenment. Cambridge: Cambridge University Press.

Wang, Zichu. 2002. Zhongguo Yinyue Kaoguxue [Chinska Archeologia Muzyczna]. Fuzhou: Fujian Jiaoyu Chubanshe.

[王子初. 2002. 中國音樂考古學.福州: 福建教育出版社.]

Weber, Max. 1978. Economy and Society: An Outline of Interpretive Sociology. Tłum. Ephraim Fischoff i in. Berkeley-Los Angeles-London: University of California Press.

Wehmeier, Sally, Michael Ashby, A.S. Hornby. 2004. Oxford Advanced Learner's Chinese Dictionary. Hong Kong: Commercial Press, Oxford University Press.

Xia, Ye. 2007. Zhongguo Yinyue Jianshi [Krótka historia muzyki chińskiej]. Beijing: Gaodeng Jiaoyu Chubanshe.

[夏野. 2007. 中國音樂簡史. 北京: 高等教育出版社.]

Xu, Ximao, Yu Yizhi. 2009. Zhongguo Yinyueshi yu Mingzuo Xinshang Puxiu Jiaocheng [Historia $i$ dzieła muzyki chińskiej]. Shanghai: Shanghai Yinyue Xueyuan Chubanshe.

[徐希茅, 喻意志. 2009. 中國音樂史與名作欣賞普修教程. 上海: 上海音 樂學院出版社.]

Xunzi. 2007. O muzyce. Adina Zemanek (red.). Estetyka chińska. Antologia. Kraków: TAiWPN Universitas, 65-92.

Yang Yinliu. 1981. Zhongguo Gudai Yinyue Shiga [Zarys historii starożytnej muzyki chinskiej]. Beijing: Renmin Yinyue Chubanshe.

[陽蔭瀏. 1981.中國古代音樂史稿. 北京: 人民音樂出版社.]

Yu Yizhi. 2010. Zhongguo Yinyueshi [Historia muzyki chińskiej]. Changsha: Hunan Yiwen Chubanshe.

[喻意志. 2010. 中國音樂史. 長沙: 湖南㙯文出版社.] 
Zang Yibing. 2005. Zhongguo Yinyueshi [Historia muzyki chińskiej]. Wuhan: Wuhan Daxue Chubanshe.

蔵一冰. 2005. 中國音樂史. 武漢: 武漢大學出版社.

\begin{abstract}
Musical Institutions in Ancient China

Since mythological times, music was considered to be a vital part of Chinese culture. Its very high social standing, deeply rooted in Confucian philosophy, resulted in the abundance of musical administration, for example, the first known musical institution was The Great Office of Music (大司樂 Dàsìyuè)of the Zhou dynasty which was responsible for teaching ritual and music; The Music Bureau (樂府 Yuèfú)of the Qin and Han dynasty that collected and edited musical pieces, and numerous agencies under court of Tang or its Shrine of Imperial Sacrifices (太常寺 Tàichángsì) managing various tasks, from education to musical performances. In the Song dynasty, musical offices followed the tradition of their predecessors, but on a much smaller scale.

The article aims to describe musical institutions of the ancient Chinese court and determine whether they can be described as a musical bureaucracy. The paper is divided into three main parts: the first outlines the term "bureaucracy" in accordance to both lexical and Max Weber's definitions; the second presents the main offices that dealt with music and its evolution; the third part functions as the conclusion, the author compares the main characteristic of musical agencies with the meaning of the term bureaucracy.
\end{abstract}

Keywords: Chinese musical institutions, traditional Chinese music, Chinese bureaucracy 